activities of the engineer and the reaction of presentday conditions on his outlook. "As engineers concerned with applied science," said Mr. Haldane, "we occupy a position intermediate between that of pure science and that of the branches of knowledge concerned with human affairs. We are very definitely concerned both with the advancement of scientific knowledge and with the problem of how this knowledge can best be applied to meet human needs. The latter function makes it particularly important that the general educational background of engineering training should be as wide as possible and should not exclude those branches of knowledge generally known as the humanities.

"The present difficulties due to the huge content of knowledge and consequent tendency towards excessive specialization have led to the disappearance at an early stage in education of any general study of religion or philosophy, so that at the age when young people are becoming able to think on such subjects the great majority proceed to concentrate on mastering the means of life and remain indifferent to, and almost oblivious of, its ends.

"Future generations may well be amazed at our acceptance of such a state of affairs, the existence of which I feel to be one of the strongest arguments in favour of the higher education of engineers being centred in the universities rather than in mono-technic colleges. Although even in the best of our universities there may be too much concentration on means and too little thought about ends, the engineering undergraduate does at least get and give the immense advantage of mixing with those who are studying totally different branches of knowledge. The whole atmosphere of a university engineering education can be influenced by contacts with the other faculties, including the humanities, and consequently study can be on a much broader basis than is possible in colleges or institutions dealing with one subject or group of subjects."

In summing up, Mr. Haldane remarked, "In providing the conditions in which the things of the spirit can come to full fruition we undertake a vital as well as a noble task in which we can have the utmost pride. But let us fully understand the nature of our task, and let us spend more time than we now do in considering the ends to which our work is directed."

\section{MODERN DEVELOPMENTS IN FORESTRY}

$\mathrm{I}^{\mathrm{N}}$

Forestry Abstracts (Commonwealth Forestry 1 Bureau, vol. 10, No. 1 Abstracts (1)-(849), September 1948, Commonwealth Forestry Bureau, Oxford), Mr. J. J. MacGregor, of the Imperial Forestry Institute, Oxford, has an interesting paper on "Some Improved Techniques in Nurseries and on Planting Sites". There are many influences, he says, compelling foresters all over the world to revise time-worn practices. These influences are part of the general economic environment in which rising wages and relative shortages of labour are, perhaps, most significant. They have directly stimulated the search for more economic methods, machines and techniques. In a general way, current and recent developments have proceeded along the two main lines of 'rationalization' and the application of new techniques to specific operations. The latter, which includes the adoption of mechanization, improved processes with new tools and new treatments, forms the basis of the article.

In using the term 'rationalization' the author means it to be applied to the administration of staff, the training of subordinate workers, housing and amenities, the execution and close inspection of all work, and the provision of tools ; on this last point of tools one might add that, until recently in ordinary forest work, they were few, simple and no different from those in existence during what may be called the pre-mechanized times. In the modern study of these methods Sweden has given the lead and has been in the position, during the past ten years, when so many were otherwise engaged, to make considerable progress; and mention must be made of Swedish reorganisation of piece-work rates, which require to be both flexible and easily understood. Both in North America and in Germany forestry experts have been making similar studies. One form of 'rationalization' has been the suggested centralization of forest nurseries, since it is held, and rightly so, that the efficient raising of large stocks requires highly skilled and experienced supervision. Whether, however, the small nursery on the private estate should be regarded as obsolete is a matter which is open to considerable argument. The big battalions are by no means the safest in a matter of this kind, for many reasons.

On the side of technical mechanical developments, North America takes the lead. In agriculture, the application of labour-saving devices has gone a long way, and a few have been adapted for forestry purposes. But it is felt that special investigations, which are indeed being carried out by those conversant with forest nursery and other wider forestry problems, will have a greater chance of giving the forester new mechanical implements suitable to his particular type of work. The article also deals with the transfer of planting stock (storage and packing), preparation of sites, stump removal, plough and cultivators (the Forestry Commission has had a considerable success based on experiments with heavy ploughs), sowing and planting, planting methods and machines.

\section{LABORATORY GLASSWARE PRODUCTION}

$T$ THE expression 'E-MIL' may not be quite so well known as some others which have become quite commonplace; but it is likely to become a mark of quality standard in future. Messrs. H. J. Elliott, Ltd., Treforest Trading Estate, Nr. Ponty. pridd, Glam., whose trade mark it is, already enjoy a reputation for high-quality glassware for quantitative work; but they laudably seek to enhance that reputation by aiming at still higher standards and by offering unconditional guarantees concerning their products, as well as improvements in the character and packaging of the articles.

In the first place, their volumetric glassware will be designated ' $\mathbf{E}-\mathrm{Mil}$ Green Line' in the case of that which complies with National Physical Laboratory grade $A$ specifications, and 'E-Mil Gold Line' for that of the grade $B$ standard, the graduations of these varieties being filled respectively with insoluble green and yellow enamels. The pigments appear to be 